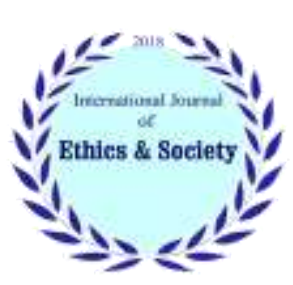

International Journal of Ethics \& Society (IJES)

Journal homepage: www.ijethics.com

Vol. 3, No. 2(2021)

(Original article)

\title{
Designing \& Validating a Model of Organizational Policy Perception Indicators Based on Political Ethics
}

\section{Abdolsamad Safarnezhad ${ }^{a}$, Mehran Mokhtari Bayekolaei Ph.D. ${ }^{b^{*}}$, Saeed Eslami Ph.D. ${ }^{c}$}

a) Ph.D student in Management, Chalous Branch, Islamic Azad University, Chalous, Iran

b) Dept. of Management, Chalous Branch, Islamic Azad University, Chalous, Iran

c) Dept. of Political Thought, Chalous Branch, Islamic Azad University, Chalous, Iran

\section{Abstract}

Background: Organizational politics within organizations, like the power around the manager, is broad and widespread, and managers consider political behavior as a part of organizational life that is inevitable, and on the other hand, the impact of ethics on social and especially political behaviors is undeniable. Therefore, the purpose of this study was to design and validate organizational policy indicators based on political ethics.

Method: The method of the present study was integrated (qualitative and quantitative) and in terms of purpose was applied research. The qualitative section consisted of experts with experience in the field of political behavior who interviewed 11 people using purposive sampling. The texts of the interviews were also analyzed by coding method. In the quantitative part, the statistical population was the heads and experts of the Ministry of Interior (101 people). The sample size was selected based on Morgan and Krejcie table of 80 people by random sampling method. The research instrument was a completed questionnaire with 3 dimensions, 10 components and 99 indicators, the reliability of which was obtained by Cronbach's alpha test of 0.91 . Structural equations with Smart Pls software were used to analyze the data.

Results: The results showed that the organizational, personal and job dimensions had $(0.57,0.44,0.37)$ direction coefficient in the organizational policy model based on political ethics, respectively, and the research variables could be 0.66 , the perception variable. Predict organizational policy based on political ethics. Also, the overall fit of the model was evaluated at a very high level $(\mathrm{GOF}=0.59)$.

Conclusion: The model of perception of organizational policy indicators based on political ethics with 3 dimensions and 10 components has a good fit and can be considered as a suitable model of political behavior in public and private organizations in Iran.

Keywords: Organizational policy, Political ethics, Organizational dimensions

* Corresponding Author: Email: mokhtari@iauc.ac.ir

Received: 08 Feb 2021

Accepted: 20 Apr 2021 


\section{Introduction}

The organization is composed of individuals and groups that have different values, goals and interests, and this causes disagreement, conflict and conflict over access to scarce organizational resources (1). Perhaps the fact that the allocation of limited resources of the organization needs to be interpreted is one of the factors in the emergence of policy in organizations (2). Political behaviors are one of the constituent elements of organizational behavior (3). Organizational policies and political behaviors are activities that enable employees to achieve their goals in the organization without having to go through appropriate formal and administrative channels (4). Political behavior is essential for complex organizations and plays an important role in the workplace (5). Some experts believe that all behaviors are in the political organization, almost everyone who works with the organization is familiar with the political activities of employees (6). Although political behavior may have both positive and negative consequences, much of past research has focused on its dark side (7). Individuals accept organizational membership in order to meet their personal needs. For this purpose, they have to communicate with each other. In fact, social interactions between individuals provide favorable conditions for the emergence of political behavior and skills (8). Successful organizations today need employees who are equipped with political skills in the organizational set (9). People who are politically skilled are socially strong and can adapt their behavior to the situation. In addition, individuals can honestly adapt their behavior to those around them (10). Researchers' studies of organizational policy have shown that political skills as an essential asset can affect performance (11). In addition, political behavior is recognized as a source of stress and conflict in the workplace, one of the potential negative consequences of which is poor performance at both individual and organizational levels. Although other negative consequences in the organization may be due to inadequate understanding of the organizational hierarchy, such as poor work relationship with the supervisor, another possible outcome of political behavior in the organization is psychological and physical leaving of work, especially absenteeism. (12).

Some studies focus on a very specific aspect of organizational policy called employee perception of organizational policy $(14,13)$. Reflects the policy perception of the extent to which other members of the organization have the power and influence to gain benefits in conflicting situations, and refers to employees' beliefs that if they perceive organizational policy, their political behavior toward others or They attribute the organizational environment to what it is (15). Perception of organizational policy is related to what level of power and influence is used by other members of the organization to gain advantages and maintain interests in conflicting situations (16). This perception is the product of an individual's interpretation of the behavior of others and organizational events, which can be positive or negative (17), although researchers believe that employees' perceptions of politics are almost always negative (18). Political behavior and organizational policy perception are dual structures that are interrelated and high levels of organizational policy perception increase the tendency to political behavior, which strengthens the policy perception itself (8). Given the strong evidence for the association of organizational policy perceptions with a variety of negative consequences for individuals and managers, organizations need to consider the factors that give rise to these perceptions (19). Some researchers believe that there are at least three potential answers to understanding organizational policy. Employees may leave the organization, stay in the organization but not get involved in politics, or may stay in the organization and engage in political activity. Based on this distinction, employees who perceive the organizational environment as political often find it stressful, ambiguous, and frustrating, and those who choose to stay and engage in politics may try to do so. Gain control of the organizational environment (6).

One of the important issues related to organizational policies is ethics. Ethics is generally concerned with the way people look at life and perceive things as good or bad (20). But ethics also has other 
sections such as economic ethics, medical ethics, social ethics or political ethics (21). Political ethics refers to the actions that individuals in a politically organized community (such as government, region, administration, etc.) adapt to living together legally, administratively, economically, educationally, or health-wise. In other words, political ethics is related to the organized actions and activities of individuals in relation to political actions (22). Ethics and politics and the relationship between the two is one of the most important issues that human beings have always faced in the course of life and has been the place of discussion and discussion of scientists and philosophers throughout history (23). Some scholars have distinguished between ethics and politics and put politics minus ethics at the forefront of their decisions and do not see any relationship between them. They have considered the morality of the policies of that society (24). The view of the unity of morality and politics emphasizes that both morality and politics seek to ensure human well-being and cannot violate each other. This doctrine considers only one moral system as valid in both spheres of individual and social life and believes in the individual level is moral, at the social and political level, and it is also moral for the statesmen, and whatever is immoral for each citizen is considered immoral for the government as well. According to this theory, ethics, individual politics, and moral politics are collective. Ethics and politics are both branches of practical wisdom and seek to ensure human well-being. Proponents of this theory believe that politics is a technique that realizes moral life (25). The relationship between ethics and politics has far-reaching practical consequences, the result of which is adherence or non-adherence to ethical principles. Adherence to political ethics also increases higher ethical performance, increases employees' organizational pride, improves organizational identity, creates a stronger ethical climate, leads to greater employee socialization and promotes institutionalized norms and expectations (26). Political ethics can also be directly related to work attitudes $(29,28)$. Furthermore, studies have shown that employees who are more skilled in political ethics have different experiences and reactions to the workplace (30).
Little research has been done on organizational policies related to political ethics, and there is a research gap in this regard. The results show that there is a significant relationship between organizational silence and perception of organizational policy and organizational commitment (31). Researchers found that there is a positive and significant relationship between perceived organizational support and organizational citizenship behavior and job performance (32). The results of studies revealing the construction of social security, social trust, feelings of powerlessness, feelings of social belonging, job status and educational status have the greatest impact on decision-making in political behavior (33). The results of other studies showed that the variables of organizational structure and organizational political behaviors are directly related to organizational effectiveness (34). Another study showed that political activity is inherent in all interactions and, therefore, is considered as one of the constituent elements of organizations (35). This kind of behavior creates a divisive and harmful work environment that has increasingly negative effects on employees. Therefore, awareness of the factors that cause political behavior plays an important role in preventing and limiting such behavior. The results showed that organizational policies (accompanying for promotion; payment and promotion policies; and general political behaviors) affect employee participation and performance (36). Another study has shown that political ethics and teaching political behaviors are effective in understanding employees' social responsibility and improve attitudes toward work (29).

A review of the literature showed that organizational politics on the one hand and political ethics on the other hand are two important structures in organizational and behavioral studies. Also, the effects of organizational policies are wide and from positive to negative consequences, and further study and understanding of organizational policies in organizations is inevitable. Another is that not many studies have been done on organizational policies in Iran from the perspective of political ethics and most studies have dealt with the relationship between two variables and mainly the impact of political behaviors on other variables. Therefore, the 
main purpose of this study is to design and validate a model of organizational policy perception indicators based on political ethics.

\section{Material \& Methods}

The method of the present study was integrated (qualitative-quantitative) and applied in terms of purpose. In the qualitative section, the participants were academic and organizational experts (11 people) who, by studying their resumes and considering criteria such as writing and familiarity with theoretical topics in the fields of political science and organizational behavior and willingness to participate in interviews, were purposefully selected (Table 1). The research tool was semi-structured interviews and coding method was used to analyze the data. For data validity from the perspective of professors and for reliability, the agreement coefficient between coders was used. The re-coding of 3 interviews showed that the agreement coefficient between coders is 0.93 .

In the quantitative part of the research, the statistical population included the heads and managers of the Ministry of Interior (101 people) and the sample size was determined using Krejcie and Morgan table (80 people) (Table 2). Simple random sampling method was also used to select the sample. The research tool was a researcher-made questionnaire that was developed based on qualitative findings. This questionnaire was designed with 3 dimensions and 10 components based on the Likert scale. Formal validity was used for the validity of the questionnaire and Cronbach's alpha test was used for reliability, which was 0.91 . To analyze the data, descriptive statistical tests (frequency and percentage) and inferential structural equations with Pls Smart approach were used.

Table1: Characteristics of experts in the quality section

\begin{tabular}{|c|c|c|c|c|c|}
\hline Variables & Factors & No & Variables & Factors & No \\
\hline \multirow[t]{3}{*}{ Age } & $30-40 y s$ & 3 & \multirow[t]{3}{*}{ Position } & Assistant & 4 \\
\hline & $41-50 y s$ & 6 & & Associate & 4 \\
\hline & over 51ys & 2 & & Prof. & 3 \\
\hline \multirow[t]{2}{*}{ Gender } & Male & 8 & \multirow[t]{3}{*}{$\mathrm{CV}$} & Related research & 4 \\
\hline & Female & 3 & & Books & 6 \\
\hline \multirow[t]{3}{*}{ Major } & Political Science & 5 & & Articles & 1 \\
\hline & Social science & 4 & \multirow[t]{2}{*}{ Education } & Ph.D. & 9 \\
\hline & Islamic studies & 2 & & Post doc. & 2 \\
\hline
\end{tabular}

Table 2: Demographic characteristics of the research sample

\begin{tabular}{|c|c|c|c|}
\hline Variables & Factors & Frequency & Percentage \\
\hline \multirow{3}{*}{ Gender } & Male & 6 & 7 \\
\cline { 2 - 4 } & Female & 74 & 93 \\
\hline \multirow{3}{*}{ Age } & $30-40 y s$ & 11 & 14 \\
\cline { 2 - 4 } & $41-50 y s$ & 41 & 51 \\
\cline { 2 - 4 } & over 51ys & 28 & 35 \\
\hline \multirow{3}{*}{ Education } & B. A & 8 & 10 \\
\cline { 2 - 4 } & M.A & 53 & 66 \\
\cline { 2 - 4 } & Ph.D. & 19 & 24 \\
\hline \multirow{3}{*}{ Work experience } & Less than 10ys & 5 & 6 \\
\cline { 2 - 4 } & $10-15 y s$ & 21 & 26 \\
\cline { 2 - 4 } & $16-20 y s$ & 30 & 38 \\
\cline { 2 - 4 } & $21-25 y s$ & 16 & 20 \\
\cline { 2 - 4 } & Over 26ys & & \\
\hline
\end{tabular}




\section{Results}

\section{Qualitative results}

The process of interview analysis showed that the perception of organizational policy based on em- ployees' political ethics is in 3 organizational dimensions with 5 components, personal with 2 components and job with 3 components. Table 2 shows the dimensions and components along with the indicators and the degree of importance of each indicator.

\section{Table 3: Dimensions and components of organizational policy perception based on political ethics}

\begin{tabular}{|c|c|c|}
\hline Dimension & Components & Indexes \\
\hline \multirow[t]{11}{*}{ Personal } & \multirow[t]{6}{*}{ Honesty } & The speech and actions of the political elite are consistent. \\
\hline & & The expression of the political elite is clear and transparent. \\
\hline & & Employees are committed to their commitments and promises. \\
\hline & & Employees have the courage to admit their mistake. \\
\hline & & Employees are honest in their day-to-day affairs. \\
\hline & & Employees are careful about the accuracy of the issues before them. \\
\hline & \multirow[t]{5}{*}{ Moderation } & Employees are moderate in behavior and speech. \\
\hline & & Employees observe justice and fairness. \\
\hline & & Employees control their emotions. \\
\hline & & Employees do not make angry decisions. \\
\hline & & Employees have dignity and self-esteem. \\
\hline \multirow[t]{12}{*}{ Professional } & \multirow[t]{4}{*}{ Rule of law } & $\begin{array}{l}\text { The job of the employees requires them to comply with the laws and reg- } \\
\text { ulations of the country in any situation. }\end{array}$ \\
\hline & & Employees adhere to and respect the laws and regulations of the country. \\
\hline & & Employees respect intellectual property rights. \\
\hline & & $\begin{array}{l}\text { Employees in their work meet ethical standards in the form of an eternal } \\
\text { law. }\end{array}$ \\
\hline & \multirow[t]{5}{*}{ Responsibility } & $\begin{array}{l}\text { Employees take on responsibilities commensurate with their capabilities } \\
\text { and perform their duties. }\end{array}$ \\
\hline & & Employees are accountable to the relevant authorities. \\
\hline & & Employees are accountable to people for their actions and behavior. \\
\hline & & $\begin{array}{l}\text { Employees take responsibility with continuous effort and avoid any loose- } \\
\text { ness and shortcomings. }\end{array}$ \\
\hline & & Employees are responsible for their own expenses. \\
\hline & \multirow[t]{3}{*}{ Services } & Employees believe in the distribution and circulation of power. \\
\hline & & Employees choose service at all costs instead of trying to gain power. \\
\hline & & $\begin{array}{l}\text { Employees adhere to national solidarity in accordance with their job re- } \\
\text { quirements. }\end{array}$ \\
\hline \multirow[t]{13}{*}{ Organizational } & \multirow[t]{7}{*}{ Preference of national interests } & In organizational policies, the interests of the system take precedence. \\
\hline & & Employees sacrifice their rights and reputation for organizational interests. \\
\hline & & $\begin{array}{l}\text { Public order in the organization takes precedence over individual and } \\
\text { group demands. }\end{array}$ \\
\hline & & $\begin{array}{l}\text { Laws and regulations in the organization take precedence over personal } \\
\text { and group demands. }\end{array}$ \\
\hline & & $\begin{array}{l}\text { Employees do not misuse information to advance personal or partisan in- } \\
\text { terests. }\end{array}$ \\
\hline & & The organization strives for national security. \\
\hline & & The services of the organization are comprehensive. \\
\hline & \multirow[t]{5}{*}{ Confidentiality } & Employees are not lax in maintaining information and are confidential. \\
\hline & & Employee privacy is respected in the organization. \\
\hline & & Classified information is stored in the organization. \\
\hline & & Important and vital information in the organization remains secret. \\
\hline & & Scoping and privacy are observed in the organization. \\
\hline & Justice & $\begin{array}{l}\text { The organization pays attention to the strengths of individuals and other } \\
\text { organizations along with their weaknesses. }\end{array}$ \\
\hline
\end{tabular}




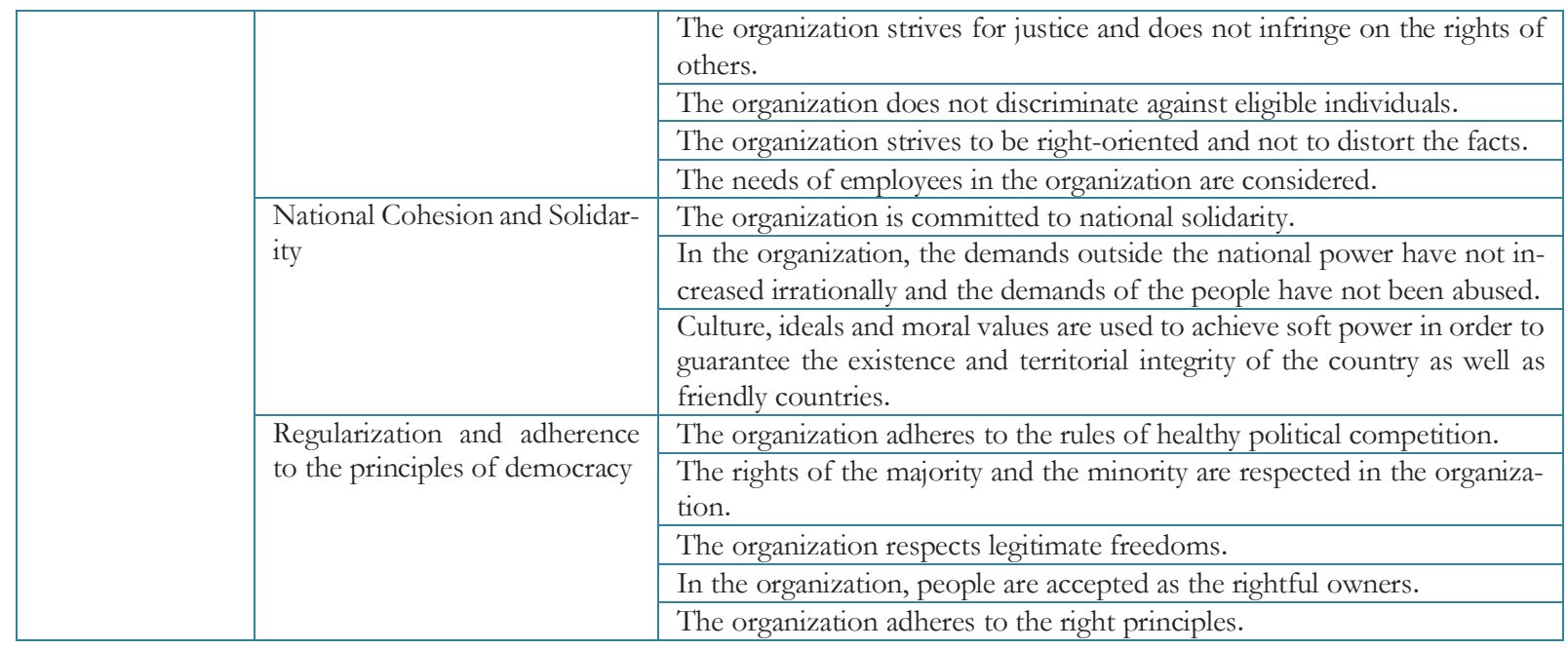

In the quantitative part of the research, structural equations have been used. First, Cronbach's alpha coefficients and combined reliability were used to evaluate the reliability of the research variables. The results are shown in Table (4).

Table 4: Cronbach's alpha results and the combined reliability of the research variables

\begin{tabular}{|l|l|l|}
\hline Concealed variables & Alpha $>\mathbf{0 . 7}$ & CR $>0.7$ \\
\hline $\begin{array}{l}\text { Perception of organizational pol- } \\
\text { icy based on political ethics }\end{array}$ & 0.740 & 0.852 \\
\hline Organizational & 0.837 & 0.883 \\
\hline Personal & 0.713 & 0.872 \\
\hline Professional & 0.740 & 0.852 \\
\hline
\end{tabular}

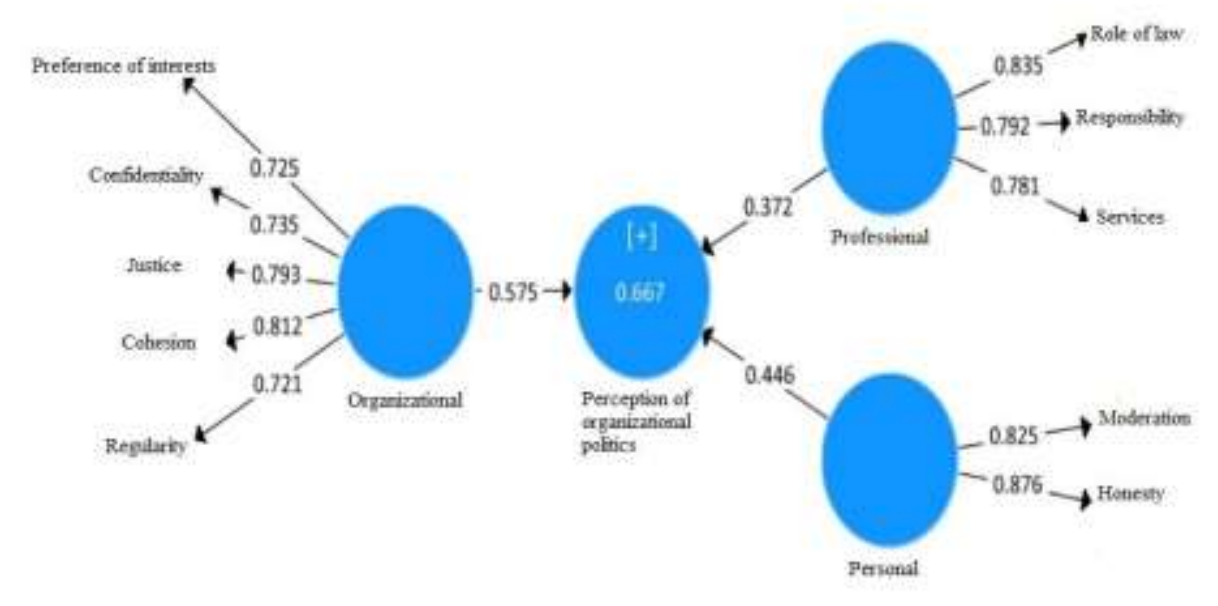

Figure 1: Test of research model in standard mode
What is the model fit of the dimensions and components of organizational policy perception based on political ethics?

Using Pls Smart software, in the first stage, the intensity and direction of the relations between the variables were reported by the standard mode test and in the second stage, by the test of significant coefficients, the significance of the relations between the variables was reported.

Based on fig. 1, the path coefficient of the organizational variable is equal to 0.57 and the path coefficient of personality and job dimensions are 0.44 and 0.37 , respectively. Accordingly, the organizational dimension is more related to political ethics than other dimensions.

Available at: www.ijethics.com 


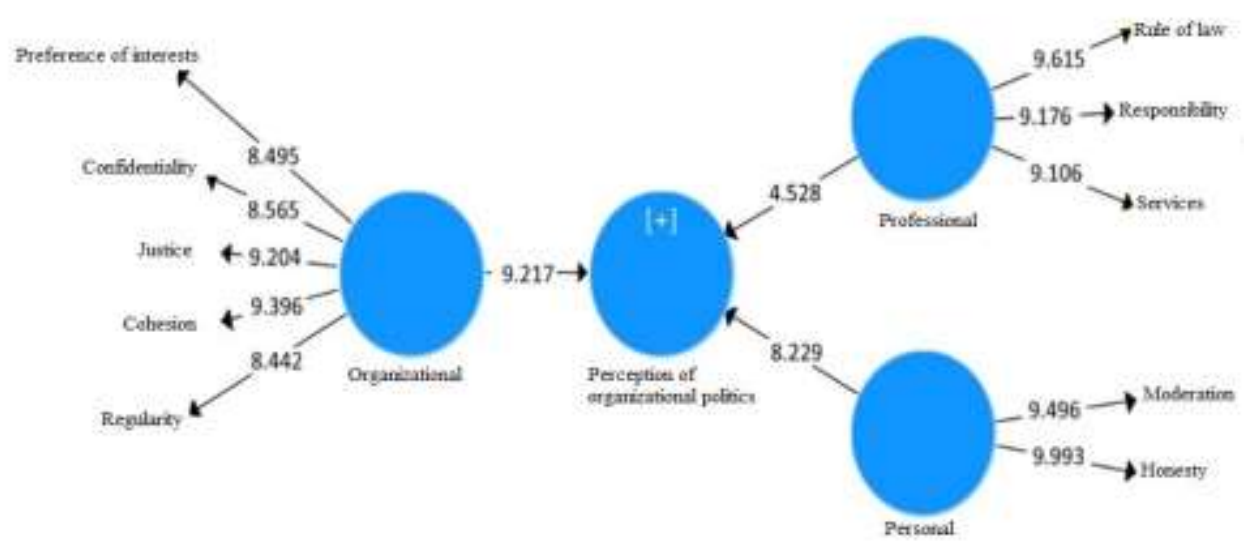

Figure 2: Research model test in the case of significant numbers

The results of Figure (2) also show that the value of t-statistic in all variables is greater than 1.96 . Therefore, the significance of path coefficient and factor loads is confirmed. In the continuation of structural equation analysis, the fit of the general model with the GOF criterion is used, which three values of $0.01,0.25$ and 0.36 are introduced as weak, medium and strong values for GOF (37)? The results of the overall model fit are presented in Table (5).

\begin{tabular}{|l|l|l|l|}
\multicolumn{4}{|c}{ Table 5: Results of GOF } \\
\hline Variable & Communality & $\mathbf{R}^{\mathbf{2}}$ & GOF \\
\hline $\begin{array}{l}\text { Perception of organiza- } \\
\text { tional policy based on po- } \\
\text { litical ethics }\end{array}$ & 0.533 & 0.667 & 0.596 \\
\hline
\end{tabular}

The results of Table 5 show that the GOF rate is 0.596 , which indicates a good fit of the overall model and the final model is approved.

\section{Discussion}

One of the most important issues for organizations is politics and political behavior, which plays an important role in the workplace. Studies have shown that organizational policies play an important role in employee growth and work environment. Accordingly, the purpose of this study was to design a model of organizational policy perception based on political ethics in the Ministry of Interior of Iran. The results showed that the three dimensions include individual-personal, occupational and organizational factors as dimensions of organizational policy perception based on political ethics, which consisted of 10 components. Statistical analysis of the data showed that in the proposed model, the organizational dimension with a path coefficient of 0.57 was in the first place of importance and then the personality and job dimensions were with a path coefficient of 0.44 and 0.37 , respectively. The results of this study are consistent with some studies; the results of a study showed that there is a significant relationship between organizational silence and perception of organizational policy and organizational commitment (28). Other results showed that perceived organizational support has a significant relationship with organizational citizenship behavior and job performance (29). The results of other studies showed that organizational structure and organizational political behaviors are directly related to organizational effectiveness (31). Other results found that political activity is inherent in all interactions and is one of the constituent elements of organizations (32). Other researchers have concluded that political ethics and the teaching of political behavior are effective in understanding the political and social responsibility of employees and improve attitudes toward work (26).

Individual-personality factors including moderation and honesty can play an effective role in un- 
derstanding organizational policy based on political ethics; In fact, political ethics is a part of personal ethics that, when there is enough in a person, can lead to positive judgments about his organization, colleagues and the workplace in general, and as a result, his political behaviors are in the path of ethics. On the other hand, it can be said that the more a person uses political ethics in his work environment in a positive way, for example, moving in the direction of his organizational interests, it also causes the growth and excellence of the organizational path. Job factors also include feedback, job independence, skill diversity, and interaction with the manager. Employees who receive constructive feedback have more control over the work environment and laws and regulations, adhere to the laws and regulations of the country, take responsibility for work with their ability, and perform their duties, believe in the distribution and circulation of power leads to understanding organizational policy. Organizational factors were another finding that affects the perception of organizational policy based on political ethics. In other words, those who participate in decisionmaking experience less job pressure that results from the perception of organizational policy, and with a preference for national interests, confidentiality, fairness, cohesion and solidarity, regularity and adherence to the principles of democracy and justice and the rights of others. Attention is paid to culture, ideals and moral values, so by observing these factors, it can affect the perception of organizational policy based on political ethics. In general, the results of structural equations showed that among the three identified dimensions, the organizational dimension had a higher path coefficient and then there are personality and job dimensions.

The limitations of the present study can be said; the present study was limited to the study of the Ministry of Interior of Iran and the generalization of the results to other organizations is subject to increasing the number of population and statistical sample. Another limitation is the lack of organizational policy models that do not provide an opportunity to compare the results of this study with other results. Also, due to the sensitivity of the policy issue, the interviewers and respondents may have given general answers and not expressed from deeper angles. Another limitation was the prevalence of coronary heart disease, which posed many challenges for the researcher to be able to easily interview volunteers or deliver questionnaires. Based on the results, it can be suggested that researchers in the future to design and explain the pattern of the impact of managerial factors on political behavior in government organizations, as well as provide a model for the interaction of perceived organizational policy and psychological capital. It is suggested that managers identify negative causes and techniques of political behavior to prevent the occurrence of negative political behavior. It is suggested that organizational goals and missions be accurately and clearly described. Another suggestion is that for organizational transparency, a special time should be set for political discussions and exchanges and views of employees so that they do not have a negative effect on the work environment outside the scope of professional political activities.

\section{Conclusion}

Organizational, personality and job dimensions are important dimensions of understanding organizational policies based on political ethics, respectively. Hence, individuals act on their perceptions of politics and in accordance with the political work ethic in the workplace, and behavioral reactions are formed based on these perceptions.

\section{Ethical Consideration}

The present study was a non-clinical study; however, the researcher explained the purpose of the research and its application to the participants and also asked their permission to record the text of the interviews. It was also ensured that the use of research data is for research purposes only and has no other use. At the end of the study, a copy of the findings was provided to the participants. 


\section{Acknowledgement}

We would like to thank all the professors and experts who cooperated in the implementation of the present study, especially the staff and esteemed officials of the Ministry of Interior of Iran who participated in the interviews despite completing their busy schedule and completed and submitted the questionnaires.

\section{References}

1. Hoy KW, Miskel GC (2013). Educational administration: theory, research, and practice. The McGraw Hill Higher Education, New York.

2. Robbins SP, Judge T (2016). Organizational behavior. Pearson International Edition, London.

3. Moshabaki A (2004). Images of onganization: a review on Gareth Morgan is valuable work about organization and metaphors. $1^{\text {st }} \mathrm{ed}$. University of Tehran, Iran. (In Persian).

4. Zaidi A, Gull S (2012). Impact of organizational politics on employees' job satisfaction in the health sector of lahore Pakistan. Joumal of Contemporary Research in Business, 4(2): 213-225.

5. Parker C P, Dipboye R L, Jackson S L (1995). Perceptions of organizational politics: An investigation of antecedents and consequences. Journal of Management, 21 (5): 891-912.

6. Jafariani H, Mortazavi S, Nazemi S, Bull P (2012). Political behavior in organizational context: Nature, research and paradigm. Management Science Letters, 2: 2987-3000. (In Persian).

7. Atinc G, Darrat M, Fuller B, Parker BW (2010). Perceptions of organizational politics: A meta-analysis of theoretical antecedents. Journal of Managerial Issues, 1: 494-513.

8. Danaeefard H, Ebrahimi Balutbazeh A, Haji Abootorab Kashi K (2010). Good soldier's perceptions of organizational politics understanding the relation between organizational citizenship behaviors and perceptions of organizational politics: evidence from Iran. European Journal of Economics, Finance and Administrative Sciences, 18:147-162.

9. Yazdani ziarat M, Rasteghar A (2019). The impact of political skills on organizational communication apprehension through the mediating role of self-esteem. Transformation Management Journal, 10(1):1-20. (In Persian).

10. Ferris GR, Treadway DC, Perrewé PL, Brouer RL, Douglas C, Lux S (2007). Political skill in organizations. Journal of Management, 33(3): 290-320.

11. Mintzberg H (1993). Structure in fives: Designing effective organizations. Prentice-Hall, Inc, USA.

12. Dargahi H (2013). Organizational behavior: ethical or unethical. IJME, 5 (7):1-14.
13. Ferris GR, Kacmar KM (1992). Perceptions of organizational politics. Joumal of Management, 18(1): 93-116.

14. Vigoda E (2002). Stress-related aftermaths to workplace politics: the relationships among politics, job distress, and aggressive behavior in organizations. International Joumal of Industrial, Occupational \& Organizational Psychology \& Behavior, 23(5): 571-91.

15. Tatarka CJ (2009). The perceptions of organizational politics in the National Guard [Ph.D. Thesis]. Northcentral University, USA.

16. Brown G, Bemmels B, Barclay LJ (2010). The importance of policy in perceptions of organizational justice. Human Relations, 63(10):1587-609.

17. Andrews MC, Kacmar KM (2001). Discriminating among organizational politics, justice, and support. International Journal of Industrial, Occupational \& Onganizational Psychology \& Behavior, 22(4): 347-66.

18. Miller BK, Byme ZS, Rutherford MA, Hansen AM (2009). Perceptions of organizational politics: A demonstration of the reliability generalization technique. Joumal of Managerial Issues, 1: 280-300.

19. Ullah S, Jafri AR, Bindost MK (2011). A synthesis of literature on organizational politics. Far East Journal of Psychology and Business, 3(3): 36-49.

20. Asadi F, Davoodi R, Mirzaei N A (2020). Identifying the components and factors affecting the professional ethics of teachers. IJES, 2 (2) :1-10.

21. Marco G (2018). The political ethics and the attribution of moral responsibility to public organizations: its scope and its limits. Emerald Publishing Limited, USA.

22. Dubbink W, Smith J (2011). A political account of corporate moral responsibility. Ethical Theory \& Moral Practice, 14(2): 223-46.

23. Molavi M (2016). Ethical principles and foundations of politics in Imam Ali's point of view. Quarterly Journal of $\mathrm{Nabj}$ al-Balagha Research, 4(14):1-18. (In Persian).

24. Kazemi AA (1997). Ethics and politics. Ghomes Publications, Tehran/Iran. Pp. 22-223. (In Persian).

25. De-Fouchecour CH (1986). Moral ethical concepts in Persian literature from the third century to the seven century. Translated by: Amir-Moezzi MA, Rouhbakhshan A. (1998). Center of Academic Publications, Tehran/Iran. P. 613. (In Persian).

26. Chua F, Rahman A (2011). Institutional pressures and ethical reckoning by business corporations. Journal of Business Ethics, 98(2):307-29.

27. Valentine S, Barnett $T$ (2002). Ethics codes and sales professionals' perceptions of their organizations' ethical values. Journal of Business Ethics, 40(3):191-200. 
28. Valentine S (2009). Ethics training, ethical context, and sales and marketing professionals' satisfaction with supervisors and coworkers. Journal of Personal Selling \& Sales Management, 29(3): 227-42.

29. Valentine S, Godkin L (2016). Ethics policies, perceived social responsibility, and positive work attitude. The Irish Journal of Management, 35(2):114-28.

30. Masoudi J, Sadatizadeh SS (2016). Relationship of moral and politics. Ethics in Science \& Technology, 10 (3): 19-28. (In Persian)

31. Salari M (2020). The relationship between organizational silence and perception of organizational policy with the moderating role of organizational commitment in the employees of bank Melli in Zabol. 1 International Conference on Challenges and New Solutions in Industrial Engineering, Management and Accounting, Sari / Iran. (In Persian).

32. Jafari P, Majedimoghadam Z (2013). Relationship between perceived organizational support, psychological capital and organizational citizenship behavior among Islamic Azad University employees, science and research branch of Tehran. The Journal of Modern Thoughts in Education, 8(4): 22-36. (In Persian).
33. Asgarpour'T, Navabakhsh M, Mohseni Tabrizi A (2018). Sociological study of the decision making process in political behaviors with an emphasis on the role of gender (case of study: Tabriz city). Journal of Iranian Social Development Studies, 10(2): 89-104. (In Persian)

34. Rahman Seresht H, Alizadeh M, Abdollahi H (2017). The effects of organizational structure and job characteristics on job satisfaction and organizational commitment. IQBQ, 20 (4):147-176. (In Persian)

35. Fani A, sheikhinejad F, Danaeefard H, Hasanzadeh A (2014). Explaining the mediating role of perception of organizational politics between employees' political behavior and individual, job and organizational factors. Organizational Culture Management, 12(1): 21-39. (In Persian)

36. Lau PY, Tong JL, Lien BY, Hsu YC, Chong CL (2017). Ethical work climate, employee commitment and proactive customer service performance: Test of the mediating effects of organizational politics. Journal of Retailing and Consumer Services, 35: 20-26.

37. Qasemi V (2011). Structural equation modeling in social research using Amos Graphics. Sociologists Publications, Tehran/Iran. (In Persian). 